\title{
INTERACTIVE LEARNING AND STUDENTS' COMPETENCES IN TEACHING LITERATURE
}

\author{
Saša Knežević, PhD, assistant prof. \\ Faculty of Philosophy East Sarajevo (Bosnia and Herzegovina) \\ e-mail: knezsa@yahoo.com \\ Branka Kovačević, PhD, assistant prof. \\ Faculty of Philosophy East Sarajevo (Bosnia and Herzegovina) \\ e-mail: kovacevicbrana@yahoo.com
}

\begin{abstract}
A b stract
Studies have shown that in everyday school activities the predominating forms of learning are characterized by individualism and competition. Such atmosphere of individualism and competition can hardly have a positive influence on the development and stimulation of students' competence in teaching literature. The focus of interactive learning is not only on cognitive competences, which the traditional teaching insists on, but also on the emotional, social and working competences, which are developed in the process of reception and interpretation of literary and artistic texts. This paper presents the results of experimental research of the effects of interactive learning on the development of students' reading skills in teaching literature. The effects of interactive learning are expressed through a higher degree of development of cognitive, emotional, social and working competences of students.
\end{abstract}

Key words: interactive learning, competences, student, teaching literature, reading, reception

\section{The theoretical framework of the research}

Contemporary teaching strategies are directed towards adapting teaching to the spirit, needs and trends of the modern time. Society is in permanent evolution: general knowledge is expanding, but there are also changes in opinions related to social interaction. Social development and its changes have a faster and faster rhythm (Roeders, 2003). The increase in general level of human knowledge has the impact on increasing the scope of teaching volume. All this presupposes a change in the planning, programming, implementation and evaluation of the previous learning strategies.

Modern teaching expects from an individual continuous learning, creativity and exploration. Students are expected not only to manage their own potentials, knowledge, skills and habits, but also to discover and examine their own talents and areas of interest. All this requires an environment that is rich (positive) in stimuli and challenges for a child (Roeders, 2003). Organization of interactive learning maximally engages the 
student, and significant effects of learning can be expected not only in the cognitive component of the student's personality, but rather in social, emotional and voluntary component too, which is by Krneta more appropriate for the needs of a young person's development. Teachers are faced with the most important task - to 'structure teaching and education in such a way that students are not focused solely on acquiring professional knowledge and skills, but also, on the personality development (creativity, self-confidence, self-esteem), and the development of social competence.' Development of social understanding in students is largely dependent on their social contacts. 'If the school introduces areas for meeting people, it can greatly assist students in developing these skills which are of great importance for their future life in society' (Roeders, 2003, 69). Students through their own and other people's experiences perceive the complex social reality (students understand the position of another person, negotiate joint actions, adhere to the promises they make and meet commitments). 'Learning situations can be planned and organized to enable students to clarify and improve their interpersonal relationships, to awaken their understanding of the tasks, problems and projects in which they are to cooperate and to achieve the satisfaction of having contributed to joint activities' (Đorđević, 1996, 203). Students should be allowed to 'reveal things for themselves, to perceive the cause-effect relation phenomena, both through individual and group work' (Roeders, 2003, 18). Students cannot be combined into one class and expected to have a social interaction. Social interaction to some extent must be prestructured.

\section{Interactive learning in teaching literature}

A large number of authors believe that the interactions in schools so far have been neglected. Interaction in the school setting is usually referred to as the framework of cooperative learning, pair work, group work, project-methods and other models used in teaching.

Interactive learning for Nenad Suzić is a 'process that results in relatively permanent changes in thinking, emotions and behaviour that arise from the experience, traditions and practices achieved in social interaction' (Suzić, 2005a, 130). Interactive learning, according to Krneta, cannot be viewed as learning at school, nor as an interaction or a simple collection of learning and interaction. The key notion in the phrase interactive learning is the concept of learning. The term interaction is a factor which precisely shows how indicated learning takes place. Therefore, the interactive learning is defined as a "method of organization of learning with others, but the learning is understood as a process that is focused on development of a young person' (Krneta, 2006, 57). This way of learning puts students in a position to work at their own pace (for as long time as they need to, at a time when it suits them, to choose collaborators who to cooperate with, and that all students have the chance to learn the planned curriculum to the level that best suits them) and that they receive the satisfaction (praise for the success or reproach for the failure). Interactive learning provides unflinching support and cooperation of students with their teachers and other students in the process of acquiring new knowledge or learning new things. 
The questions of the precise structure and class organization in interactive teaching are even easier to solve than the traditional types of teaching. This goes especially for the study of literary works. Long ago it became clear that students do not understand literary works in the same way as adults do and that they need help of more competent readers in understanding literary and artistic works. This caused the modification of the conventional structures that existed in the theory of reception, and they were then, in the work with children, transformed into the following pattern:

$$
\text { WRITER - WORK - ADULT READER - THE READER (student) }
$$

The concept of a CRITICAL TEXT can be added in this scheme before or after the term ADULT READER, but it is certainly more efficient to be found on the communication range behind the term ADULT READER, following the attitude of Živan Živković 'When it comes to the population of younger-age readers, the critical text does not exercise a direct relationship with the recipient.' (Živković 1990, 118) Of course, teachers must use literary text as part of assistance to students in reading, and not as a set pattern which would be followed by dogmatically reproductive student analysis. As literary texts are studied in teaching in the form of home readings, this implies that students read the work and come to class with a reception which is in accordance with their capabilities and prior knowledge. Teacher's role in this case is primarily based on the stimulation of creative reading and reading comprehension, to think about what they read and what they have read, as Wolfgang Kaiser puts it 'overall theoretical engagement in poetry serves primarily to the large and difficult art of reading.' (Kaiser 1973, 8)

It is important that the teacher monitors and encourages students in this difficult art because the reception of a literary text is primarily an individual phenomenon, in which the pedagogue is expected to show all the qualities of a creative teacher, a good organization, modelling, assistance, research, initiating and directing where the main source of fun should be in their own and their students' creativity. (Marinković 2000, 19) In this process all the benefits of interactive teaching stand out, and they confirm that in understanding and interpreting literary works there are no pre-set axioms and that it is an extremely individualized process in which a teacher (ADULT READER) as a moderator, primarily has a function to keep things under control. The ultimate purpose of the permanent interaction of students and teachers, and students with each other is the intelligent exercise that is open and directed towards new achievements. In studying such a complex phenomenon it is advisable to use different teaching methods for different kinds of texts, and combining methods when literary text are studied in the class, where a more important role is that of a teacher, but primarily in the encouraging and organizational way.

Interactive learning in the teaching of literature has a distinctive functional unity of the three pedagogical strategies of teaching, learning and self-study. Contemporary pedagogical paradigm of interactive learning in teaching includes functional synthesis of components: student, teacher, teaching or learning activities or educational process. 'This pedagogical paradigm thus consists of the interaction between subjects who are learning, contents they are learning and the teaching process applied for learning" (Branković, 2005, 253). The essence of interactive learning is expressed in the 
interdependence and interaction, or cross-impact of the subjects exposed to mutual learning. The psychological basis of interactive learning is located in cooperation, which is essentially a separate and very complex personality trait. In the process of learning, cooperation is practically manifested through the willingness to work with others (working in a collective, group or pair), the willingness to establish equal and reciprocal relations with others, and the great trust and tolerance towards those we learn with. 'Cooperation is expressed by those students who have developed empathic abilities and can control their emotions and desires' (Branković, 2005, 253). It should not be overlooked that not all students have developed capabilities for cooperative work. It is therefore necessary to develop the ability for cooperative work by training. The teaching process can be a favourable atmosphere for exploring cooperative skills not only for students but also for teachers. A special system of social support according to Roders (2003) is found in people apply their own mental resources in solving problems together, pursuing common goals and mutually providing the necessary funds to deal with situations that cause stress. 'Interactive learning, individual or combined with lectures, can be implemented on such principles in all teaching positions (front, group, working in pairs, individual), but with different educational effects' (Branković, 2005, 254). The results have shown that students better master the curriculum and are more motivated when working in a group than when working alone (Johnson and Johnson, 1999). Sources of these motivations are manifold: cooperative work, learning to give and receive help, mutual learning of new ways how to remember things, solve problems, explain things to each other, etc. (Webb, Troper and Fall, 1995). There are also other motives accompanying interactive learning which are not inherent to traditional teaching (Suzić, 2005a). The question arises whether interactive learning has a stimulating effect on students? An analysis of pedagogical and psychological literature and the results of a small number of empirical studies have shown that the interactive learning has connections between lectures (teaching) and interactive learning in groups (learning and self-study). It should not be overlooked that differences in the learning process are always manifested in the interdependence and interaction.

\section{Opportunities for developing and enhancing competences of students in teaching literature}

In the organization of teaching literature one has to start from the fact that a child experiences a literary text primarily in aesthetic way and then experiences it. 'Normally, a child is a being of imagination and free senses; the child is beyond morality and restraint outside the convention ('the child as such'). The child is ready, especially for pure literature and play, which stipulates the fact that children's literature has the largest share of aesthetic value. In the second place there is a cognitive value, while we place ethical only as third. (Pogačnik 1980, 14) Modern interpretations of literature regard literary work as a sign, the primary element of communication, a part of communicative series discussed earlier. "The sign is always directed to someone, with the expectations to be "deciphered and interpreted."'(Lešić 2008, 69) At this point, Marko Sorijano's definition seems functional 'a book for children is the message that an adult transmitter (locator) of a certain time and certain socio-cultural environment prepares and publishes, 
using existing roads, for pleasure and, if possible, the education of the recipient, a certain age - the age for learning - which still does not have the maturity, knowledge and, in short, a "code" which has an adult person to be able to perceive and analyse the reality.' (Sorijano 2009, 1991)

Interactive teaching is based precisely on the interpretation, the communication by information in order to improve the level of students' proficiency, and to produce new ideas for teachers. The teacher has an advantage of being intellectually mature and having the reading experience, but children's narrow horizon of expectations is the basis for a new dimension for understanding literature that was intended for them, but created by adults, because the 'Childish understanding is, in other respects, a certain case.' (Pojkert 2009, 74)

Hence, the student has a certain advantage because he/she understands the text in more appropriate, truer way. This means that the children's competence in understanding these texts is even greater than the teacher's and therefore the interaction is necessary. Feedback that an ADULT READER gets comes from, for a given artefact, a more competent reader. Of course the teacher is more competent and has developed a critical approach, but they should use their competence primarily at the level of reporting and modelling work in the classroom, as they have to 'respect a child's freedom at any cost, first because it is worthy of respect, then because the goal we have set to ourselves requires an active participation of the child.' (Sorijano 2009, 1992) The main task of teachers is the organization of classes in which all students, according to their desires and abilities, demonstrate their judgments about the text they have read, and create a positive atmosphere for the inclusion of students with different knowledge and reading skills, and to create an atmosphere in which students are willing to hear opposing views and discuss them, 'the teacher should begin by making sure that the children they are responsible for wish and succeed in expressing themselves, that they wish to converse; which would create a desire with them to express themselves to others, and also create a respect for them with others' (Sorijano 2009, 91) In an atmosphere of respecting different opinions and judgments, a positive interaction can be developed that will lead to new insights.

\section{Research Methodology}

Our aim was to identify and analyse the impact of interactive learning on the development of students' competences in teaching of literature.

Hypothesis. It is assumed that interactive learning affects the development of students' competences in teaching literature.

The sample in the research had the characteristics of a group and of a random sample. It comprised 250 students, of which 125 experimental and 125 students in the control group. Students of the ninth grade are characterized by numerous changes related to: physical growth and development, intellectual development, social development (living space is expanding and differentiating, the number of roles available to adolescents nowadays increases, and there is the possibility of active experimentation with different roles) and emotional development (increased autonomy from parents, seeking emotional resources outside the family). Selected classes were the ninth grade 
that did not stand out particularly for their success and behaviour, neither in a positive or negative sense, with the aim of balancing gender, success and motivation (means are slightly different, the differences were not statistically significant).

Teachers-experimenters were of the same sex, educational level, approximate age and years of experience. The teachers in the Interactive Learning Project were acquainted with the aspects and possibilities of evaluating interactive learning.

Methods and techniques. We used the following methods in the research: experimental method, empirical-nonexperimental research and methods of theoretical analysis and synthesis.

The survey instrument. For the purposes of the research we constructed a scale for assessing students' competences in teaching literature. The Scale of assessments measures cognitive, emotional, social and working competences in teaching literature.

The course of research. The experiment was done in two primary schools in East Sarajevo (eight classes of which four classes were experimental and four controlled). Experimental and controlled groups were working under similar conditions. The difference is that interactive learning was introduced in the experimental group (four classes).

Techniques of statistical analysis. We calculated: arithmetic average, standard deviation and t-test.

\section{Results and discussion}

Results of students' competences development in teaching literature in the initial survey are presented in tabular form.

Table 1.The overall results of the initial testing on students' competences in teaching literature in the experimental and control groups

\begin{tabular}{|c|c|c|c|c|c|c|}
\hline group & $\begin{array}{c}\text { no of } \\
\text { students }\end{array}$ & average & $\begin{array}{c}\text { standard } \\
\text { deviation }\end{array}$ & $\begin{array}{c}\text { standard } \\
\text { error }\end{array}$ & $\mathrm{t}$ & $\mathrm{P}$ \\
\hline $\mathrm{E}$ & 112 & 17,75 & 3,69 & 0,35 & \multirow{2}{*}{1,081} & 0,282 \\
\hline $\mathrm{K}$ & 112 & 17,15 & 4,21 & 0,40 & \\
\hline
\end{tabular}

Based on the results obtained, we can conclude that the difference between the average values in experimental and control group was not statistically significant, the obtained t-ratio $(1.081)$ was not statistically significant at 0.05 level $(1.081<1.96)$, or at the level of $0.01(1.081<2.58)$.

At the final testing, after the influence of experimental factor, we found a statistically significant preference for the experimental group. The obtained results of the final testing are presented in the table. 
Table 2.The overall results of the final testing on students' competences in teaching literature in the experimental and control groups

\begin{tabular}{|c|c|c|c|c|c|c|}
\hline group & $\begin{array}{c}\text { No of } \\
\text { students }\end{array}$ & Average & $\begin{array}{c}\text { Standard } \\
\text { deviation }\end{array}$ & $\begin{array}{c}\text { Standard } \\
\text { error }\end{array}$ & $\mathrm{t}$ & $\mathrm{P}$ \\
\hline $\mathrm{E}$ & 112 & 19,38 & 2,80 & 0,26 & \multirow{2}{*}{5,986} & \multirow{2}{*}{0,000} \\
\hline $\mathrm{K}$ & 112 & 16,48 & 3,92 & 0,37 & 5,92 \\
\hline
\end{tabular}

Comparing the results from the table we can conclude that the students from the experimental group achieved the average of 2.90 points higher than the same parameter in the control group. This difference was statistically significant at both levels of reliability, $0.05(5.986>1.96)$ and $0.01(5.986>2.58)$ in favour of the experimental group. Based on the calculated $t$ value we can claim with the probability of $99 \%$ to the risk of $1 \%$ that interactive learning achieves greater effects in developing students' skills in teaching literature.

We tried to determine what the results were within each group in terms of the results before and after the experiment, both in the control and experimental group. The overall results achieved by the experimental and control groups in the initial and final testing of competences in teaching literature are presented in tables and graphs.

Table 3. The overall results of the initial and final testing on students' competences in teaching literature in the experimental and control groups

\begin{tabular}{|c|c|c|c|c|c|c|c|}
\hline group & is & $\begin{array}{c}\text { No of } \\
\text { students }\end{array}$ & Average & $\begin{array}{c}\text { Standard } \\
\text { deviation }\end{array}$ & $\begin{array}{c}\text { Standard } \\
\text { error }\end{array}$ & $\mathrm{t}$ & $\mathrm{p}$ \\
\hline \multirow{2}{*}{$\mathrm{E}$} & $\mathrm{I}$ & 112 & 17,75 & 3,69 & 0,35 & 8,476 & 0,000 \\
& $\mathrm{~F}$ & 112 & 19,38 & 2,80 & 0,26 & & \\
\hline \multirow{2}{*}{$\mathrm{K}$} & $\mathrm{I}$ & 112 & 17,15 & 4,21 & 0,40 & \multirow{2}{*}{1,254} & \multirow{2}{*}{0,213} \\
\hline
\end{tabular}

It is evident that changes have occurred in the experimental group under the influence of experimental factors. Examinees in the experimental group had progressed compared to our own results at the beginning of the experiment (17.75 to 19.38). The difference between their average generated before and after the start of the experiment is 1.63 , t-ratio (8.476) is statistically significant at both levels of reliability, that is at the 0.05 level $(8.476>1.96)$ and at $0.01(8.476>2.58)$. In the control group there has been a decline. The difference between the average values obtained in the initial and final testing was not statistically significant. The resulting t-ratio (1.254) was not statistically significant at any level of reliability $(1.254<1.96$ at $0.05,1.254<2.58$ at 0.01$)$. Based on the findings of research we can conclude that the students of experimental group made greater effects in developing competences in teaching literature.

The results above confirm that the major effects of the development of students' competences in teaching literature are expressed through: 1) the willingness of students to work with each other, 2) the willingness of students to have equal and reciprocal relationship with other students, 3) the faith of students in their own forces (the students believe that their own activities are of great benefit to other students and teachers) 4) a great deal of trust and tolerance for their fellow students 5) understanding others, 
consent, compliance with the goals of the group or organization, losing that feelings of fear in the face to face communication.

\section{Conclusion}

Based on the above mentioned research results we can conclude that the importance of interactive learning in teaching literature is undisputable. But it is not always possible and reasonable to apply the procedures of interactive learning. Starting from this Drago Branković said: 'interaction in the learning process, especially in the teaching process can have different guidelines, from that of being the method of organization of learning with others to the fact that the meaning of the term is raised to the level of the educational system'. Regardless of differences in terminologicalconceptual sphere, interactive learning in the class has quite a few advantages over the traditional learning in the classroom.

Basic principles of individual behaviour, according to Krneta (2006) can and should be applied to the behaviour of students in the teaching process. It is therefore essential that the school provides the individual with a greater freedom of choice and the chance for taking various activities. Later we can expect from the student as an individual more prominent initiative in addressing important issues in personal and social life. Changes in the educational process imply a change of position of students in the process of teaching. According to Krneta this contributes to enabling students for effective learning, i.e. for learning that encourages the harmonious development of one's personality. Do the learning-oriented effects sufficiently meet the needs of modern man or the system of educational needs to introduce more development-oriented models? For us an especially interesting question is whether the changed role of an individual in society can be realized through old methods of learning organizations or there is a need to search for some new models of learning (learning with other people outside school, i.e. the immediate and wider social environment). The results of our study show that the "literary analysis at schools is essentially a kind of continuation of experiential research and reading.' (Nikolić1999, 259) Reading literary texts should primarily be enjoyable for students so that an interaction could be established between the reader and the work as a necessary prerequisite for further interaction of readers of different reading skills and horizons of expectations. This method enables an increase of reading skills and students' reading habits in time, where the most significant cause of alarming cultural illiteracy of young generations is their lack of reading habits, which is one of the largest general and cultural phenomena of modern civilization.

\section{References}

Branković, D. (2005): Interaktivno učenje u nastavi-nova pedagoška paradigma. U zborniku: Banjalučki novembarski susreti nauka i obrazovanje (str. 245-259). Banja Luka: Filozofski fakultet.

Ilić, P. (2010): Književnost za decu i razredna nastava, presudni činioci trajnog odnosa prema knjizi, kulturi i stvaralaštvu. U Zborniku: Savremeni trenutak književnosti za decu u nastavi i nauci (str. 227-238). Vranje: Učiteljski fakultet. 
Johnson, D.W. and Johnson, R.T. (1999): Making cooperative learning work. Theory Into Practice, 38, $67-74$.

Kajzer, B. (1973): Jezičko umetničko delo. Beograd: SKZ.

Krneta, D. (2006): Interaktivno učenje i nastava. Banja Luka: FPDN.

Kovačević, B. (2007): Uticaj interaktivne nastave na formiranje moralne autonomije učenika završnih razreda osnovne škole. Naša škola, 3-4, 5-20.

Lešić, Z. (2008): Teorija književnosti. Beograd: Službeni glasnik.

Ličina,S., Šekara, L., Gaković, V., Stefanović, S. (2005): Čitanka za deveti razred osnovne škole. Istočno Sarajevo: Zavod za udžbenike i nastavna sredstva.

Marinković, S. (2000): Metodika kreativne nastave srpskog jezika i književnosti. Beograd: Kreativni centar.

Nikolić, M. (1999): Metodika nastave srpskog jezika i književnosti. Beograd: Zavod za udžbenike i nastavna sredstva.

Pogačnik, J. (1980): Problem dečje književnosti - pojam i recepcija. U Zborniku: Dečja književnost - pojam i recepcija, Detinjstvo, br. 2. (str. 13-23). Novi Sad.

Pojkert, K.V. (2009): Prilog antropologiji knjige za decu. U Zborniku: Princeza luta zamkom (str. 73-86). Novi Sad: Zmajeve dečje igre.

Roeders, R. (2003): Interaktivna nastava-Dinamika efikasnog učenja i nastava. Beograd: Institut za pedagogiju i andragogiju Filozofskog fakulteta u Beogradu.

Sorijano, M. (2009): Književnost za omladinu i njena vaspitna primena. U Zborniku: Princeza luta zamkom (str. 87-96). Novi Sad: Zmajeve dečje igre.

Suzić, N. (2005): Pedagogija za XXI vijek. Banja Luka: Teacher Training Centre.

Webb, N., Troper, J. and Fall, R. (1995): Constructive activitx and learning in collaborative small groups. Journal of Educational Psychology, 87, 406-423.

Živković, Ž. (1990): Mesto i uloga književne kritike u recepciji i proučavanju književnosti za decu. U Zborniku: Dete i knjiga danas (str. 116-120). Novi Sad: Zmajeve dečije igre. 
Metodički obzori 6(2011)3

Izvorni znanstveni rad

UDK: $371.3: 82$

Primljeno: 21. 6. 2010.

\title{
INTERAKTIVNO UČENJE I KOMPETENCIJE UČENIKA U NASTAVI KNJIŽEVNOSTI
}

\author{
Doc. dr Saša Knežević \\ Filozofski fakultet \\ Univerzitet u Istočnom Sarajevu \\ e-mail: knezsa@yahoo.com \\ Doc. dr Branka Kovačević \\ Filozofski fakultet \\ Univerzitet u Istočnom Sarajevu \\ e-mail: kovacevicbrana@yahoo.com
}

\begin{abstract}
Sa žetak
Istraživanja su pokazala da u svakodnevnim školskim dešavanjima dominiraju oblici učenja koje karakteriše individualizam i takmičenje. Teško da atmosfera individualizma i takmičenja može uticati na razvijanje i podsticanje kompetencija učenika u nastavi književnosti. Fokus interaktivnog učenja nije samo na kognitivnim kompetencijama na čemu insistira uobičajena nastava nego i na emocionalnim, socijalnim i radno-akcionim kompetencijama. U radu su prezentovani rezultati eksperimentalnog istraživanja uticaja interaktivnog učenja na razvijenost kompetencija učenika u nastavi književnosti. Efekti interaktivnog učenja ispoljavaju se kroz veći stepen razvijenosti kognitivnih,emocionalnih, socijalnih i radno-akcionih kompetencija učenika.
\end{abstract}

Ključne riječi: interaktivno učenje, kompetencije, učenik, nastava književnosti, čitanje, recepcija 